\title{
Global Cities: Introduction
}

English version

\section{Lawrence Phillips}

\section{(2) OpenEdition \\ Journals}

Electronic version

URL: http://journals.openedition.org/transtexts/129

DOI: $10.4000 /$ transtexts. 129

ISSN: 2105-2549

Publisher

Gregory B. Lee

\section{Printed version}

Date of publication: 1 September 2007

Number of pages: 1-2

ISSN: 1771-2084

\section{Electronic reference}

Lawrence Phillips, «Global Cities: Introduction», Transtext(e)s Transcultures 跨文本跨文化 [Online], 3 | 2007, Online since 13 September 2009, connection on 22 September 2020. URL : http:// journals.openedition.org/transtexts/129; DOI : https://doi.org/10.4000/transtexts.129 


\section{Global Cities: Introduction}

\section{LAWRENCE PhILLIPS}

Is the 'global' city an age-old historical phenomenon associated with economic, cultural, and imperial power (Rome, Athens, Beijing, Istanbul), or a consequence of the industrial revolution? Is it a product of the media age or a continuation of the power and influence of the imperial metropolis? In the nineteenth and for much of the twentieth century it would have been claimed as a Western imperialist phenomenon (London, Paris, New York) or cities and countries that consciously emulated western imperialism (Tokyo). This conception - if ever actually true certainly cannot be supported today. The European and north American cities now vie with the booming cities of Asian Tigers (Mumbai, Shanghai, Seoul), and the great developing cities (Mexico City, Sao Paulo, Bahía Blanca, Lagos), as well as regional expressions like the 'Pacific Rim' cities.

What is the essence of the 'global' city and how has it been represented? Is it a modern phenomenon or an ancient practice? How do we define global - is globalism a consequence of mass urbanisation or does globalisation create the conditions for the emergence of the global city. How do the global cities of the twentieth century resemble or differ in form and function those of the past and, based on present trends, the future? In the 21st century more people than even will be living in urban environments: "Over the next thirty years, the world's urban population could double from 2.6 billion in 1995 to 5.2 billion in 2025. Most of this growth will take place in developing countries, where some 4 billion people (over half of the total) could be living in cities by 2025, compared with 1.5 billion (37\%) in the early 1990s». ${ }^{1}$ How will this impact on how we imagine the city and issues of

${ }^{1}$ Michel Andrieu, «The City in the Global Village», OECD Observer, n 217-218 Summer 1999. 
migration, diaspora, and existing geopolitical inequalities - not all global cities are equal in these terms. What have been and will be the consequences of such global economic and technological inequalities?

Such questions are of course as open ended as the phenomenon to which they respond. If there is a problem of definition, the potential ways in which the "global» city might be represented and discussed are as equally plural. The issue recalls James Donald's observation that «by calling this diversity «the city», we ascribe to it a coherence or integrity». If even the basic notion of the city requires a strategy to contain its diversity and create a «textual» illusion of integrity, what of the global city surely an even vaster construct? Donald proceeds to draw a comparison between Benedict Anderson's notion of the nation as an imagined community and the way we conceive of a construct an abstract notion of the city as imagined environment. ${ }^{2}$ This approach runs the risk of implying that the city is a psychological construct and cultural process as purely discursive space rather than lived experience, as Henri Lefebvre warns: «this mental space then becomes the locus a «theoretical practice» which is separated from social practice and which sets itself up as the axis, pivot or central reference point of knowledge». ${ }^{3}$ However, Donald is surely right to argue that the city is as much a psychological construct as material/social space. The global city is also part of an even greater imagined environment that implies a unity brought about by world-wide communications networks and a certain homogenization of the physical fabric of the city, particularly in the developed world but increasingly around the globe.

The conference at Liverpool Hope University in the UK in 2006 which generated this special issue of Transtext(e)s Transcultures on global cities, provided a forum whereby scholars from a variety of backgrounds shared techniques and insights on selected cities from the developed and developing world, North and South, the brash and new to ancient and care worn, from North America, Africa, the Near and the Far East. It is hoped that the selection herein captures something of the spirit of shared insight and debate into the phenomenon of the global city.

\footnotetext{
${ }^{2}$ James Donald, «Metropolis: The City as Text», in R. Bocock and K. Thompson (eds), Social and Cultural Forms of Modernity, Cambridge: Polity Press, 1992, p. 427.

${ }^{3}$ Henri Lefebvre, The Production of Space, trans. Donald Nicholson-Smith, Oxford UK and Cambridge USA: Blackwell, 1997, p. 6.
} 